\title{
The First Occurrence of Stem Canker on Oilseed Rape Caused by Leptosphaeria biglobosa in Serbia
}

\author{
Petar Mitrović ${ }^{1}$ Ana Marjanović Jeromela ${ }^{1}$ Vojislav Trkulja² \\ Željko Milovac ${ }^{1} \cdot$ Sreten Terzićc
}

${ }^{1}$ Institute of Field and Vegetable Crops, Maksima Gorkog 30, 21000 Novi Sad, Serbia

${ }^{2}$ Agricultural Institute of the Republic of Srpska, Knjaza Miloša 17, 78000 Banja Luka, Republic of Srpska, Bosnia and Herzegovina

\begin{abstract}
Summary: In October 2010 the occurrence of the stem canker symptoms in rapeseed was observed at the locality Rimski Šančevi in Serbia. Several strains of fungi were isolated from the stem. Morphological characteristics of the isolates were studied on a PDA medium at $25 \pm 1{ }^{\circ} \mathrm{C}$ : growth rate, colour, shape and appearance of colonies and the edge of the colony, the pigment, size, colour and shape of pycnidiospores and pycnidia in 10 isolates (isolated in Serbia K-111, K-112, K-113, K-114, K-115, K-116, K-117, K-118, K-119, and K-120). All tested strains had fast growth, the regular form of colonies and poor sporulation on nutrient medium. Pycnidiospores are unicellular, hyaline, and mostly straight, with or without a drop of oil. Molecular identification was performed by the application the PCR technique using primers PN3/PN10. In addition to these 10 isolates, two reference strains obtained from the Centre for Agricultural Studies, Rothamsted, UK, which are marked with L. m (Leptosphaeria maculans), L. b (Leptosphaeria biglobosa) and 7 reference isolates originating from Serbia, which are marked K-7, St-16, GS-25, L-5, C-3, LJ-2, S-1 were used. On the basis of DNA amplification with primers PN3 and PN10 tape length was about 580 bp for isolates (L.b, K111, K-112, K-113, K-114, K-115, K-116, K-117, K-118, K-119, K-120) while that was 560 bp for other group of isolates (L.m, K-7, St-16, GS-25, L-5, C-3, LJ- 2, S-1). This study showed that 10 isolates (K-111, K-112, K-113, K$114, \mathrm{~K}-115, \mathrm{~K}-116, \mathrm{~K}-117, \mathrm{~K}-118, \mathrm{~K}-119, \mathrm{~K}-120$ ) isolated from the stem of rapeseed belong to the species Leptosphaeria biglobosa.

Key words: oilseed rape, Leptosphaeria biglobosa, morphological characteristics, molecular characteristics
\end{abstract}

\section{Introduction}

Stem canker is an economically important disease of rapeseed in Europe, Australia and North America (Fitt et al., 2006). This disease is caused by two types of phytopathogenic fungi of Leptosphaeria complexes: Leptosphaeria maculans (Desm.) ces. and de Not anamorph Phoma lingam (Tode. Fr.) Desmas, which causes canker of stem base and Leptospaeria biglobosa Shoem and Brun, which causes symptoms of canker on upper stem parts. L. biglobosa mostly causes minor damages (Rouxel \& Balesdent, 2005), while serious damages can be caused in countries with higher temperatures in summer (Huang et al., 2005; Fitt et al., 2006). L. maculans is present in Africa, Central and South America and Asia (Anon. 2004 cit. loc Fitt et al., 2006). Until mid-1990, the single cause of rapeseed stem canker in Poland was L. biglobosa (Jedryczka et al., 1994). However, Karolewski et al. (2002) state that L.

Corresponding author:

petar.mitrovic@ifvcns.ns.ac.rs

Acknowledgments

This study was supported through the project TR 31025 financed by Ministry of Education, Science and Technological Development of the Republic of Serbia. maculans is widespread in the western part and $L$. biglobosa in the eastern part of Poland. In the Czech Republic and Hungary both species of fungi occur (Szlavik et al., 2003), while in Russia L. biglobosa is dominant (Jedryczka et al., 2002). West et al. (2001) and Fitt et al. (2008) state that only L. biglobosa was isolated in China. On the territory of the former Republic of Yugoslavia (SFRY), Phoma lingam (teleomorph Leptosphaeria maculans (Desm.) Ces. de Not was spotted on cauliflower near Split for the first time (Panjaninin, 1965). Cvjetković et al. (1983) also state that although it was quarantined, the parasite was spotted in many production regions in Yugoslavia. In Serbia, parasitic fungus Phoma lingam was isolated from cabbage (Mitrović, 1997). It was isolated from rapeseed in 1987 in Negotin and during 1988 in Leskovac (Antonijević, 1999). During 2005 and 2006 P. lingam was registered in all production regions of rapeseed in Vojvodina (Mitrović \& Marinković, 2007). In the earlier period, populations of fungus L. maculans were divided in two groups based on their pathogenicity and described as aggressive or non-aggressive (McGee \& Petrie, 1978; Koch et al., 1989; Badawy \& Hoppe, 1989). Based on RFLP analysis, Johnson \& Lewis (1990) divided it into group A and B while Balesdent et al. (1992) divided it on $\mathrm{Tox}^{+}$isolates which produce phytotoxins and $\operatorname{Tox}^{0}$ 
which do not produce sirodesmins. In Australia, epidemic is caused only by the group A, while in Canada and Western Europe, damage is caused by both groups (West et al., 2001). Pathogen L. biglobosa causes small brown spots with or without pycnidia in the spots (Brun et al., 1997; Thürwächter et al., 1999). Balesdent et al. (1992), Brun et al. (1997) and West et al. (1999) state that, apart from leaf blight, B group can also cause infestation of stem pith. Shortly after harvest, pseudothecia can be observed in the base parts of the stem, while a few weeks later it can be observed on the upper part of the stem (Hammond 1985 cit. loc. West et al., 1999). The strongest leaf infections were observed at temperatures $15-20{ }^{\circ} \mathrm{C}$ and leaf wetness duration for 48 hours (Toscano-Underwood et al., 2001). Based on RFLP analysis non-aggressive isolates can be divided into three subgroups: NA1, NA2, and NA3 (Koch et al., 1991; Gall et al., 1995). Gall et al. (1995) state that NA1 subgroup is dominant in Europe, while NA2 is present in Canada. Balesdent et al. (1998) suggested the possibility of identification of species and subspecies within Leptosphaeria complex based on the ITS restriction profile, by using 5 enzymes AluI, BamHI, HaeIII, EcoRII and RsaI. On the basis of the obtained results, Balesdent et al. (1998) divided Leptosphaeria complex into seven groups: (1) Brassica Tox ${ }^{+}$, (2) Lepidium Tox $^{+}$, (3) Brassica Tox $^{0}$ NA1 subgroup, (4) Brassica Tox $^{0}$ NA2 subgroup, (5) Brassica Tox $^{0}$ NA3 subgroup (6) Erysimum Tox $^{0}$ and (7) Thlaspi Tox ${ }^{0}$. Apart from molecular and virulent characteristics, there is a difference between the isolates in the production of phytotoxin sirodesmin PL (Koch et al., 1989). Besides sirodesmin PL, the culture filtrate contained other sirodesmins (sirodesmin B, C, H, K) (Badawy \& Hope, 1989; Pedras \& Seguin-Swartz, 1992; Pedras et al., 2007; Pedras et al., 2008; Mitrović et al., 2012). The presence of host unspecific sirodesmins in the culture filtrate enabled isolate grouping into $\operatorname{Tox}^{+}$or $\operatorname{Tox}^{0}$ (Balesdent et al., 1992; Fitt et al., 2006). The presence of two different RFLP profiles, connected with differences in pathogenicity and pigment production in liquid culture, enables classification of isolates into A (highly aggressive Tox $^{+}$) or B (non-aggressive Tox ${ }^{0}$ ) group (Fitt et al., 2006). Without RFLP analysis the aggressive (virulent) isolates can be placed into group A based on the production of sirodesmin PL and the inability of forming pigment on a liquid Czapek agar (Brun et al., 1997). Label for the B group was used for nonaggressive isolates, not producing sirodesmin but forming pigment on a liquid Czapek agar (Williams \& Fitt, 1999). Research conducted earlier indicates that isolates of the A group have a slow and irregular growth on agar plates, while B group isolates exhibit a fast and regular colony shape (Humpherson-Jones, 1986; Koch et al., 1989). Picnydiospores are colourless, cylindrical, unicellular, mostly straight, some curved, with or without oil drops on the edges (Hong et al., 2009). Under in vitro conditions, repeated differences in the morphology of single ascospores and crossing of the opposite types of pairing $\mathrm{A}$ with $\mathrm{A}$, or $\mathrm{B}$ with $\mathrm{B}$, indicate that two groups of different species were named Leptosphaeria maculans for A group and Leptosphaeria biglobosa for NA1 B group (Somda et al., 1997; Shoemaker \& Brun, 2001). Based on molecular characteristics, host type and geographical origin Mendes-Pereira et al. (2003) divided Leptosphaeria complex into seven groups: Leptosphaeria biglobosa brassicae, Leptosphaeria biglobosa canadensis, Leptosphaeria biglobosa erysimi, Leptosphaeria biglobosa thlaspii, Leptosphaeria biglobosa australensis, Leptosphaeria maculans brassicae i Leptosphaeria maculans lepidii. The aim of this research was to determine the presence of fungi Leptosphaeria biglobosa in Serbia, as the causal agent of stem canker in rapeseed, and also to study morphological and molecular characteristics of the pathogens.

\section{Materials and Methods}

\section{Isolation and Isolate collection}

Ten isolates of fungi were isolated from the infested parts of rapeseed stem collected at the locality Rimski Šančevi during October 2010. Fragments of infested tissue were submerged in a $3 \%$ sodium hypochlorite solution for 3 to 5 minutes, washed with distilled water and dried naturally. After drying, fragments of infested tissue were placed on a Potato Dextrose Agar (PDA) (Difco Detroit USA). To prevent the development of bacteria, $50 \mathrm{mg}$ of streptomycinsulfate/1 (Galenika Beograd, Serbia) was added to the agar. Petri dishes with PDA were placed in a thermostat at $25 \pm 1^{\circ} \mathrm{C}$. For obtaining purified monosporous isolates the following was used: pycnidiospores, released from pycnidia as a gelatinous drop, were transferred in plastic test tubes with $2 \mathrm{ml}$ of sterile distilled water, using a tip of a spear needle. The $2 \mathrm{ml}$ of prepared suspension of conidia was poured into Petri dishes. After 48 hours, germination of conidia was examined under the binocular. Germinated conidia with a small part of the agar were transferred onto a PDA and incubated in a thermostat at $25 \pm 1^{\circ} \mathrm{C}$. Such obtained ten monosporous fungal isolates were used in further research. Two reference isolates were used, received from the Centre for Agricultural Research, Rothamsted, GB, labelled as L.m (Leptosphaeria maculans) and L.b (Leptosphaeria biglobosa), and seven reference monosporous isolates from Serbia labeled as K-7, St-16, GS-25, L-5, C-3, LJ2, S-1 (Leptosphaeria maculans).

\section{Morphological characteristics}

Macroscopic traits of fungal isolates (growth, appearance and colour of mycelia, appearance of colony edges, the presence of fruiting bodies, and pigment secretion) were examined on a PDA at $25 \pm 1{ }^{\circ} \mathrm{C}$ (for all 10 isolates tested and 5 chosen control isolates), as well as microscopic traits - mycelium texture, appearance, 
size, shape and colour of pycnidiospores and pycnidia (Muntanjola-Cvetković, 1987). The trial was set up in four replications. Mycelial growth of the isolates was measured in $\mathrm{cm}$ on days 5,10 and 15 .

Pigment formation on a liquid Crapek agar plate

For the purpose of dividing isolates and affiliation to their respective groups of the tested fungi ( $L$. maculans and L. biglobosa), pigment formation was analysed on a liquid Czapek agar. Agar was placed into the test tubes $(10 \mathrm{ml}$ per tube) and sterilized in the autoclave at $120^{\circ} \mathrm{C}$ for 20 minutes. After cooling, fungal mycelium of all tested isolates was placed onto the agar and under the photoperiod of $12 \mathrm{~h}$ at $20{ }^{\circ} \mathrm{C}$ (McGee \& Petrie 1978). Pigment formation was monitored for 4 weeks, based on the changes in colour of the agar.

\section{DNA extraction}

Mycelia and pycnidia were scraped from the agar and put into plastic bags. After grinding mycelia and pycnidia, $800 \mu$ CTAB buffer was added to the mortar, and the mixture was transferred into $2 \mathrm{ml}$ tubes. Tubes were placed in the incubator at $65^{\circ} \mathrm{C}$ for $1 \mathrm{~h}$, and each $15 \mathrm{~min}$ the content of tubes was vortexed for $5 \mathrm{~min} .600$ $\mu \mathrm{l}$ chloroform was added to the tubes after incubation and it was vortexed in the incubator at $25^{\circ} \mathrm{C}$ for 10 seconds. Tubes were then centrifuged for $10 \mathrm{mins}$ at $1300 \mathrm{~g}$ for separation of the solid and liquid phase. Liquid phase (cca $500 \mu \mathrm{l})$ was transferred into new tubes and $300 \mu \mathrm{l}$ of isopropanol was added. Incubation was conducted for another $10 \mathrm{mins}$ at room temperature and then centrifuged for 10 mins at $1300 \mathrm{~g}$. After centrifuge the liquid was poured from the tubes, and $600 \mu \mathrm{l}$ of $70 \%$ ethanol was added. Tubes were vortexed for 10 seconds in the incubator and then centrifuged for 10 mins at $1300 \mathrm{~g}$ after which liquid was poured from the tubes. Opened tubes were placed on a dryer at $50{ }^{\circ} \mathrm{C}$ for $10 \mathrm{~min}$. The obtained residue was dissolved in $100 \mu \mathrm{l}$ TE buffer, then placed at room temperature for a few minutes, and finally frozen at $-20{ }^{\circ} \mathrm{C}$ (Day \& Shattock, 1997).

\section{PCR analysis}

Two primers were used for DNA amplification PN3 (5'CCGT'TGGTGAACCAGCGGAGGGATC) and PN10 (TCCGCTTATTGATATGCTTAAG), Balesdent et al. (1998). PCR reaction was obtained at the volume of $25 \mu \mathrm{l}$ containing: $1 \mu \mathrm{l}$ fungal (L. maculans and L. biglobosa) DNA $11 \mu \mathrm{l}$ PCR water $12.5 \mu \mathrm{l}$ master mix REDTaq (Sigma aldrich) with $\mathrm{MgCl} 2$ (Taq polimerase $0.06 \mathrm{U} / \mu \mathrm{l} 3 \mathrm{mM} \mathrm{MgCl} 20.002 \%$ gelatine 0.4 $\mathrm{mM}$ dNTP) and $1.25 \mu \mathrm{l}$ of each primer. The mixture was briefly centrifuged and the tubes then placed into the PCR apparatus (Eppendorf master cycler gradient). Each cycle consisted of $30 \mathrm{~s}$ at $94^{\circ} \mathrm{C}, 30 \mathrm{~s}$ at $58^{\circ} \mathrm{C}$ and $1 \mathrm{~min}$ at $72^{\circ} \mathrm{C}$. Total of 37 cycles were performed. After PCR amplification fragments were visually observed at $1.5 \%$ agarose gel coloured with ethidium bromide.

\section{Results and Discussion}

Symptoms

The first emergence of brown irregular spots on stem base of rapeseed was observed during the second half of October 2010 (Fig. 1). Although the increase in the number of spots occurred over time, involving a larger tissue area, delayed growth or decay of the infested plants was not observed. Based on the visual observation, only the necrosis of surface tissue was detected during autumn. Based on the cross-section and longitudinal section of infested plants during the second half of the growing period (spring), further decay of infested tissue was detected. Besides delayed growth, infested plants had fewer side stems and flowers during inflorescence, which resulted in yield decrease.

\section{Morphological characteristics}

Colonies circular in shape grew on a PDA medium after 5 days (at $25{ }^{\circ} \mathrm{C} \pm 1{ }^{\circ} \mathrm{C}$ ), and were observed in isolates: K-111, K-112, K-113, K-114, K-115, K-116, K117, K-118, K-119, K-120 and L.b. Mycelia was loose, coloured white to white smoke. Isolates from the second group (L.m, K-7, St-16, GS-25, L-5, C-3, LJ-2, S1) formed colonies with irregular round shape and lobular edges after 5 days (Fig. 2).

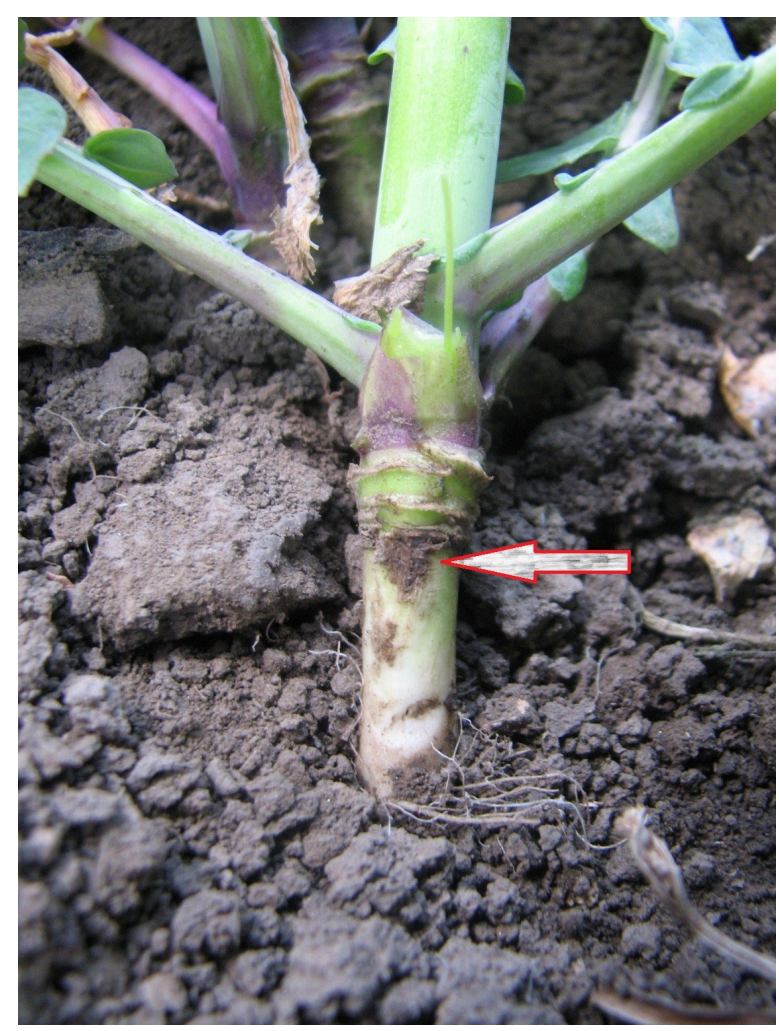

Figure 1. Symptoms of base stem canker in rapeseed (blackleg) 


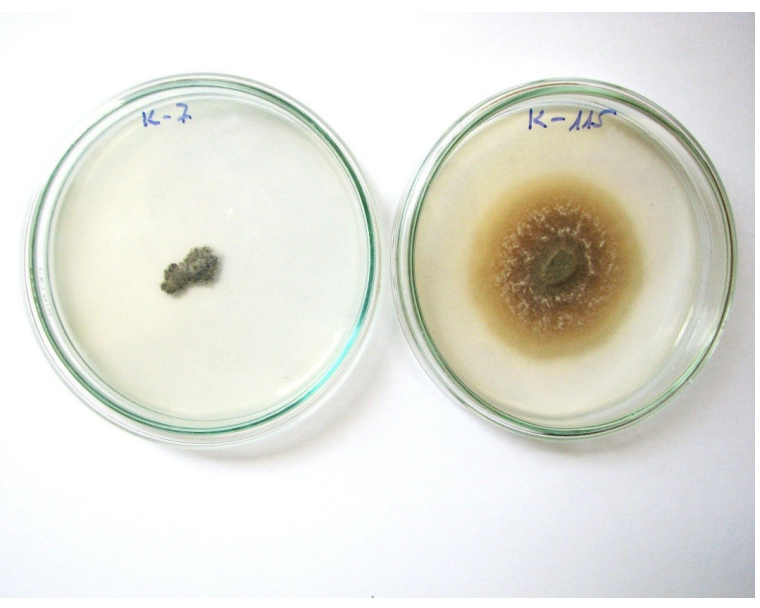

Figure 2. Appearance of the colony within the tested isolates (right) and the reference isolate (left)
After 15 days $(\mathrm{K}-111, \mathrm{~K}-112, \mathrm{~K}-113, \mathrm{~K}-114, \mathrm{~K}-115$, $\mathrm{K}-116, \mathrm{~K}-117, \mathrm{~K}-118, \mathrm{~K}-119, \mathrm{~K}-120$ and L.b) intensive formation of the yellow-brown pigment occurred in substrate mycelia (Fig. 4). The appearance aerial mycelia and substrate mycelia of the tested isolates $(\mathrm{K}-112$ and $\mathrm{K}-115)$ is shown in Figures 3 and 4. stromatic

Pycnidia were round-shaped, brown, single or

Diameter of pycnidia in group 1 (L.b, K-111, K112, K-113, K-114, K-115, K-116, K-117, K-118, K$119, \mathrm{~K}-120)$ ranged from 240 to $480 \mu \mathrm{m}$, and in group 2 (L.m, K-7, St-16, GS-25) it ranged from 220 to $510 \mu \mathrm{m}$. Pycnidia released pycnidiospores in a gelatinous drop, beige to pink in colour. Pycnidiospores are unicellular, hyaline, cylindrical, mostly straight or slightly curved, with or without drops on edges sized 1.30-2.20 $\mu \mathrm{m} x$ $2.80-5.40 \mu \mathrm{m}$ in all tested isolates. Mycelial growth and sporulation of the tested isolates is shown in Table 1.

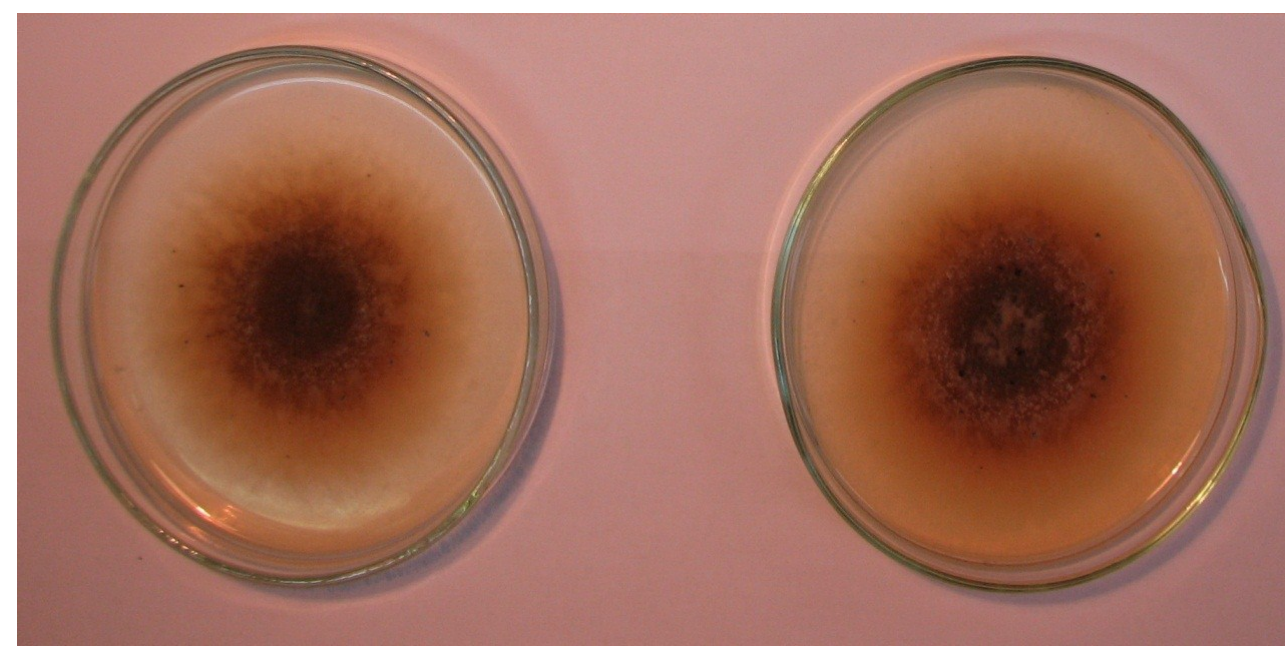

Figure 3. Aerial mycelia of isolates K-112 and K-115 on a PDA medium

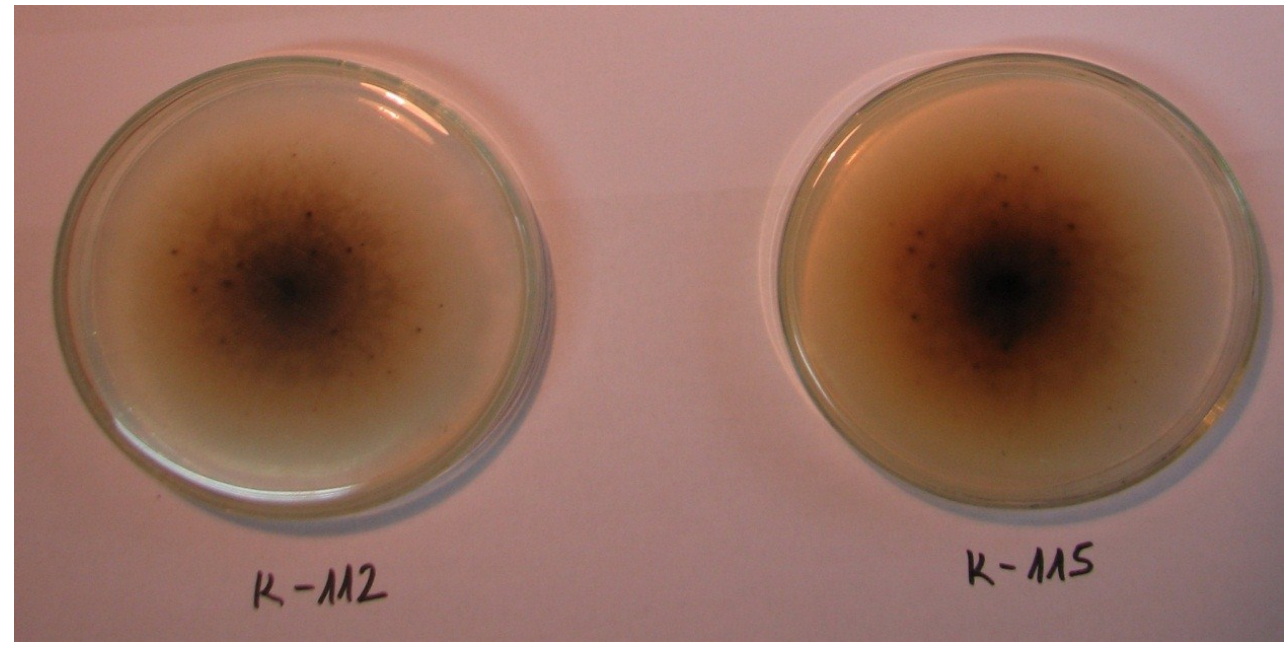

Figure 4. Substrate mycelia of isolates K-112 and K-115 on a PDA medium 
Table 1. Diameter $(\mathrm{cm})$ and sporulation of tested isolates and reference isolates on a PDA at $25 \pm 10 \mathrm{C}$

\begin{tabular}{|c|c|c|c|c|c|c|}
\hline Isolate & After 5 days & Sporulation & After 10 days & Sporulation & After 15 days & Sporulation \\
\hline K-111 & 1.57 & - & 4.02 & + & 9 & + \\
\hline K-112 & 1.50 & - & 4.42 & + & 9 & + \\
\hline $\mathrm{K}-113$ & 1.50 & - & 4.35 & + & 9 & ++ \\
\hline K-114 & 1.60 & - & 4.40 & + & 9 & ++ \\
\hline K-115 & 1.57 & - & 4.45 & - & 9 & + \\
\hline $\mathrm{K}-116$ & 1.67 & - & 4.35 & + & 9 & + \\
\hline $\mathrm{K}-117$ & 1.73 & - & 4.60 & + & 9 & ++ \\
\hline K-118 & 1.80 & - & 5.00 & - & 9 & + \\
\hline $\mathrm{K}-119$ & 1.55 & - & 4.55 & - & 9 & + \\
\hline $\mathrm{K}-120$ & 1.48 & - & 4.35 & + & 9 & ++ \\
\hline L.b & 1.55 & - & 4.30 & - & 9 & - \\
\hline $\mathrm{K}-7$ & 1.57 & - & 2.95 & ++ & 4.60 & +++ \\
\hline L.m & 1.51 & - & 3.30 & ++ & 4.70 & +++ \\
\hline St-16 & 1.48 & - & 2.95 & ++ & 3.90 & +++ \\
\hline GS-25 & 1.50 & - & 2.40 & + & 3.05 & +++ \\
\hline
\end{tabular}

- No sporulation; + Weak sporulation; + + Medium sporulation; + + + Strong sporulation

Based on the data from Table 1, it was observed that isolates $\mathrm{K}-111 \mathrm{~K}-112, \mathrm{~K}-113, \mathrm{~K}-114, \mathrm{~K}-115, \mathrm{~K}$ 116, K-117,118,119,120, and reference isolate L.b exhibited fast growth and slow sporulation on a PDA compared to other reference isolates (L.m, K-7, St16,GS-25).

\section{Pigment formation on liquid Crapek agar}

For the purpose of isolates separation, based on pigment formation on liquid Czapek agar, it was observed that after 30 days isolates $\mathrm{K}-111, \mathrm{~K}-112$, $\mathrm{K}$ 113, K-114, K-115, K-116, K-117, K-118, K-119, and K -120 produced or excreted a yellow-brown pigment, compared to isolates L.m, K-7, St-16 and GS-25 which did not produce pigment.

\section{PCR analysis}

DNA was amplified with the use of PN3 and PN10 primers (Fig. 6). Tape M 3000 bp marker. 1 L.b, 2 K111, 3 K-112, 4 K-113, 5 K-115, 6 K-116, 7 K-7, 8 GS25, 9 St-16, 10 L-5, 11 C-3, 12 LJ-2, 13 S-1, 14 L.m. In isolates $\mathrm{L} . \mathrm{b}, \mathrm{K}-111, \mathrm{~K}-112, \mathrm{~K}-113, \mathrm{~K}-115$ and $\mathrm{K}-116$ tape length was 580 bp while in L.m,K-7, GS-25,St-16, L-5,C $-3, \mathrm{LJ}-2$ and S-1 tape length was $560 \mathrm{bp}$. Based on tape length, L.b, K-111, K-112, K-113 and K-115 belong to L. biglobosa while L.m, K-7, GS-25, St-16, L-5, C-3, LJ-2 and S-1 belong to L. maculans.

Stem canker of rapeseed is caused by two types of phytopathogenic fungi of Leptosphaeria complex: Leptosphaeria maculans (Desm.) ces. and de Not (anamorf Phoma lingam (Tode. Fr.) Desmas), causing base stem canker, and Leptospaeria biglobosa Shoem and Brun, causing symptoms of canker in the upper stem parts, mostly with minor damages, while serious damages can be caused in countries with higher temperatures in summer (Huang et al., 2005; Fitt et al., 2006). During 2010, parasitic fungi were isolated from the base stem. The first symptoms were expressed in the form of irregular brown spots without the presence of pycnidia in accordance with the report of Brun et al. (1997). Further necrosis of inner tissue and delayed growth

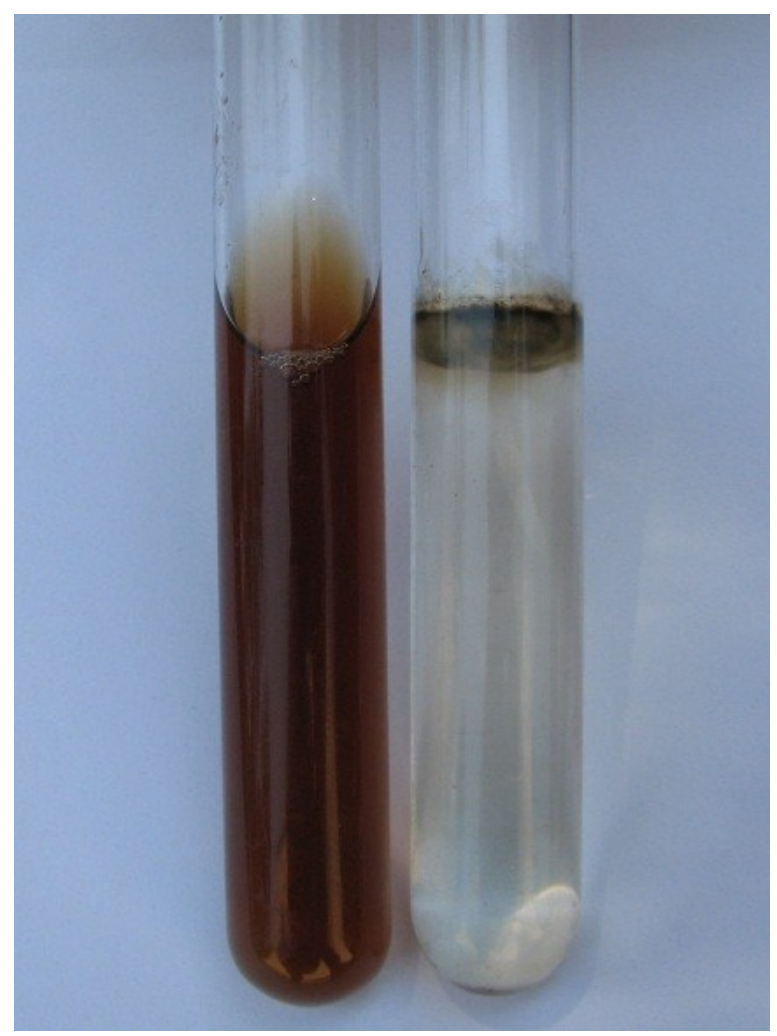

Figure 5. Pigment formation on liquid Czapek agar 
occurred in the second part of the vegetation period, which is in conformity with reports of Balesdent et al. (1992) and Brun et al. (1997). During the initial phases of growth on a PDA agar and afterwards, all tested isolates exude aerial mycelia grey-white in colour while substrate mycelia were milky white at first, as reported by Williams \& Fitt (1999) and Fitt et al. (2006). After some time, formation of black pigment was observed on the agar in isolates of group 2 (Pound, 1947; Humpherson-Jones, 1986; Williams \& Fitt, 1999; Mitrović \& Marinković, 2007), while isolates of group 1 form a yellow-brown pigment on the agar PDA (Fitt et al., 2006; Hong et al., 2009).

The tested isolates of group 1 exhibit fast growth with a regular edge on a PDA, while isolates of group 2 exhibit slow growth with irregular, often lobular edges, as reported by Pound (1947), Koch et al. (1989), Mitrović \& Marinković (2007), Williams \& Fitt (1999), McGee \& Petrie (1978), and Humpherson-Jones (1983, 1986). Koch et al. (1989) states that the isolates from group A (L. maculans) exhibit a slow irregular growth on several agar plates while isolates from group B ( $L$. biglobosa) exhibit a fast regular growth. However, there is a report stating that isolates from group A (L. maculans) exhibit faster growth than the isolates from group B ( $L$. biglobosa), and hence are difficult to distinguish on agar plates (Delwiche 1980 cit. loc. Williams 1992; Kharbanda \& Stevens, 1993; Salisbury et al., 1995). Nevertheless, based on the morphological and biochemical traits, Koch et al. (1989), Petrie (1988), Hill et al. (1984) divided the isolates into aggressive and non -aggressive strains.

All tested isolates on the PDA medium formed round-shaped, brown-coloured, single or stromatic pycnidia. Pycnidia diameter in group 1 isolates ranged from 240 to $480 \mu \mathrm{m}$, while in group 2 it ranged from 220 to $510 \mu \mathrm{m}$, in accordance with the reports of Punithalingam \& Holliday (1972) and Hong et al. (2009). Morphology and size of pycnidiospores measured in this research were similar as reported by other authors (Punithalingam \& Holliday, 1977; Williams, 1992; Mitrović \& Marinković, 2007; Hong et al., 2009; Fernando \& Ghanbarnia, 2007; Cai et al., 2014). Isolates K-111, K-112, K-113, K-114, K-115, K-116, K117, K-118, K-119 and K-120 produced yellow-brown pigment on a Czapek liquid agar compared to L.m, K-7, St -16 and GS-25 which did not produce the pigment. The presence of yellow-brown pigment places isolates in a group of non-aggressive strains in conformity with the reports of Bonman et al. (1981), Koch et al. (1989), Williams \& Fitt (1999), Kuusk et al. (2002). PN3 and PN10 primers in tested isolates L.b, K-111, K-112, K-113, $\mathrm{K}-115, \mathrm{~K}-116, \mathrm{~K}-117, \mathrm{~K}-118, \mathrm{~K}-119$ and K-120 amplify DNA at $580 \mathrm{bp}$ for isolates Leptosphaeria biglobosa or at 560 bp for isolates L.m, K-7, GS-25, St-16, L-5, C-3, LJ-2 and S-1 for Leptosphaeria maculans (fig.6.). Similar finding was reported by Balesdent et al. (1998), while MendesPereira et al. (2003) report 468 bp in Leptosphaeria maculans $\left(\mathrm{Tox}^{+}\right.$reference isolates), and $496 \mathrm{bp}$ for Leptosphaeria biglobosa NA1, NA2 and NA3 subgroup.

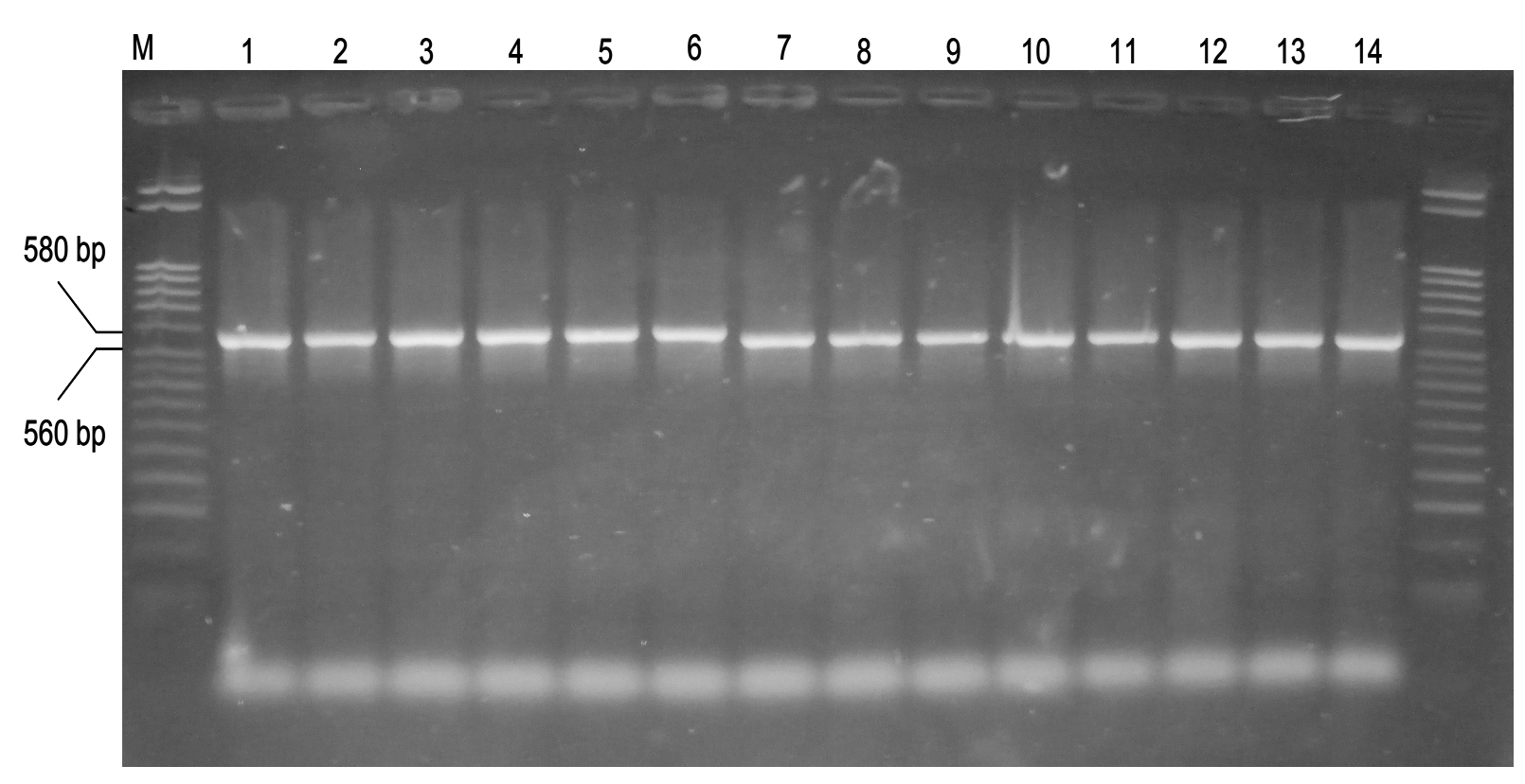

Figure 6. Polymorphism obtained by amplification of DNA using PN3 and PN10 primers 


\section{Conclusions}

Through the comparison of morphological and molecular characteristics, besides L. maculans, the presence of $L$. biglobosa can also be confirmed in Serbia. Isolates K111, K-112, K-113, K-114, K-115, K-116, K-117, K-118, K-119 and K-120 morphologically exhibit regular and fast mycelial growth on PDA unlike the isolates of $L$. maculans (L.m, K-7, St-16, GS-25, L-5, C-3, LJ-2, S-1) used as control. Mycelia in all tested isolates were smoke-white in colour. Isolates K-111, K-112, K-113, K-114, K-115, K116, K-117, K-118, K-119, and K-120 formed a yellowbrown pigment on a liquid Czapek agar, as opposed to L.m, K-7, St-16 and GS-25. Based on DNA amplification with PN3 and PN10 primers, tape length in K-111, K-112, K-113, K-114, K-115, K-116, K-117, K-118, K-119 and K -120 was 580 bp, while in L.m, K-7, St-16, GS-25, L-5, C-3, LJ-2, S-1, it was $560 \mathrm{bp}$. Based on the conducted research, the presence of pathogenic species Leptosphaeria biglobosa in Serbia can be confirmed.

\section{References}

Antonijević, D. (1999). Gljivične bolesti uljane repice u SR Srbiji (Fungal diseases of rapeseed in Serbia). Master's Thesis. University of Belgrade, Faculty of Agriculture.

Badawy, H. M. A., \& Hoppe, H. H. (1989). Nonspecific Phytotoxic Effects of Sirodesmins on Host and Nonhost Plants of Leptosphaeria maculans. J. Phytopathology, 127, 137-145.

Badawy, H. M. A., \& Hoppe, H. H. (1989). Production of Phytotoxic Sirodesmins by Aggressive Strains of Leptosphaeria maculans Differing in Interactions with Oil Seed Rape Genotypes. J. Phytopathology, 127, 146-157.

Balesdent, M. H., Gall, C., Robin, P., \& Rouxel, T. (1992). Interspecific variation in soluble mycelial protein and esterase patterns of Leptospheria maculans French isolates. Mycological Research, 96, 677-684.

Balesdent, M. H., Jedryczka, M., Jain, L., Mendes-Pereira, E., Bertrandy, J., \& Rouxel, T. (1998). Conidia as a substrate for internal transcribed spacer-based PCR identification of components of the Leptosphaeria maculans species complex. Phytopathology, 88, 1210-1217.

Bonman, J. M., Gabrielson, R. L., Williams, P. H., \& Delwiche, P. A. (1981). Virulence of Phoma lingam to cabbage. Plant Disease, 65, 865 $-867$.

Brun, H., Levivier, S., Eber, F., Renard, M., \& Chevre, A. M. (1997). Electrophoretic analysis of natural populations of Leptospheria maculans directly from leaf lesions. Plant Pathology, 46, 147-154.

Cai, X., Yang, L., Zhang, J., \& Li, G. Q. (2014). First Report of Leptosphaeria biglobosa Causing Black Leg on Raphanus sativus in Central China. Plant Disease, 98(7), 993.

Cvjetković, B., Kišpatić, J., \& Milatović, I. (1983). Morfološke i kulturalne karakteristike patogena uljane repice novog za Jugoslaviju. Zaštita bilja, 34(4), 66.

Day, J. P., \& Shattock, R. C. (1997). Aggressiveness and other factors relating to displacement of populations of Phytophtora infestans in England and Wales. European Journal of Plant Pathology, 103, 379391.

Fernando, W. G. D., \& Ghanbarnia, K. (2007). First Report on the Presence of Phoma Blackleg Pathogenicity Group 1 (Leptosphaeria biglobosa) on Brassica napus (Canola/Rapeseed) in Iran. Plant Disease, 91(4), 465.

Fitt, B. D. L., Hu, B. C., Li, Z. Q., Liu, S. Y., Langer, R. M., Kharbanda, P. D., Butterworth, M. H., \& White, R. P. (2008). Strategies to prevent spread of Leptosphaeria maculans (phoma stem canker) onto oilseed rape crops in China; costs and benefits. Plant Pathology, 57(4), 652-664.
Fitt, B. D. L., Brun, H., Barbetti, J. M., \& Rimmer, R. S. (2006). World -wide importance of phoma stem canker (Leptospheria maculans and L. biglobosa) on oilseed rape (Brassica napus). European Journal of Plant Pathology, 114, 3-15.

Gall, C., Balesdent, M. H., Desthieux, I., Robin, P., \& Rouxell, T. (1995). Polymorphism of $\operatorname{Tox}^{0}$ Leptospheria maculans isolates as revealed by soluble protein and isozyme electrophoresis. Mycological Research, 99, 221-229.

Hill, C. B., Xu, X. H., \& Williams, P. H. (1984). Correlations of virulence growth rate pigment production and allozyme banding patterns which differetiate virulent and avirulent isolates of Leptosphaeria maculans. Eucarpia. Cruciferae News, 9, 79.

Hong, S. K., Kim, W. G., Shin, D. B., Choi, H. W., Lee, Y. K., \& Lee, S. Y. (2009). Occurrence of stem canker on rape caused by Leptosphaeria biglobosa in Korea. Plant Pathol. J. 25(3), 294-298.

Huang, Y. J., Fitt, B. D. L., Jedruczka, M., Dakowska, S., West, J. S., Gladders, P., Steed, J. M., \& Li, Z. Q. (2005). Patterns of ascocpora release in relation to phoma stem canker epidemiology in England(Leptosphaeria maculans) and Poland (L. biglobosa). European Journal of Plant Pathology, 111, 263-277.

Humperson-Jones, F. M. (1986). The occurrence of virulent pathotypes of Leptospheria maculans in brassica seed crops in England. Plant Pathology, 35, 224-231.

Humperson-Jones, F. M. (1983). Pathogenicity studies on isolates of Leptosphaeria maculans from brassica seed production crops in south-east England. Annals of Applied Biology, 103, 37-44.

Jedryczka, M., Nikonorenkov, V. A., Levitin, M., Gasich, E., Lewartowska, E., \& Portenko, L. (2002). Spectrum and severity of fungal diseases on spring oilseed rape in Russia. International Organisation for Biological control Bulletin, 25, 13-20.

Jedryczka, M., Lewartowska, E., \& Frencel, I. (1994). Properties of Phoma lingam (Tode ex fr.) Desm. Isolates from Poland:Pathogenicity characterisation. Phytopathologia Polonica, 7, 71 -79 .

Johnson, R. D., \& Lewis, B. G. (1990). DNK polymorphism in Leptosphaeria maculans. Physiological and Molecular Plant Pathology, 37 , 417-424.

Karolewski, Z., Kosiada, T., Hylak-Nowosad, B., \& Nowacka, K. (2002). Changes in population structure of Leptospheria maculans in Poland. Phytopathologia Polonica, 25, 27-34.

Kharbanda, P. D., \& Stevens, R. R. (1993). Seed testing for blackleg of Canola. Vegreville AB Canada: AECV93-E1.

Koch, E., Song, R., Osborn, C. T., \& Williams, P. H. (1991). Relationship between pathogenicity and phylogeny based on restriction fragment lenght polimorphism in Leptospheria maculans. Molecular Plant-Microbe Interactions, 4, 341-349.

Koch, E., Badaway, A. M. H., \& Hope, H. H. (1989). Differences between aggressive and non-aggressive single spore lines of Leptospheria maculans in cultural characteristics and phytotoxin production. J. Phytopathol. 124, 52-62.

Kuusk, A. K., Happstadius, I., Zhou, L., Steventon, L. A., Giese, H., \& Dixelius, C. (2002). Presence of Leptosphaeria maculans Group A and Group B Isolates in Sweden. J. Phytopathology, 150, 349-356.

McGee, D. C., \& Petrie, G. A. (1978). Variability of Leptospheria maculans in relation to blackleg of oilseed rape. Phytopathology, 68, 625-630.

Mendes-Pereira, E., Balesdent, M. H., Brun, H., \& Rouxel, T. (2003). Molecular phylogeny of the Leptosphaeria maculans - Leptosphaeria biglobosa species complex. Mycol. Res. 107(11), 1287-1304

Mitrović, P. M., Orčić, D. Z., Sakač, Z. O., Marjanović-Jeromela, A. M., Grahovac, N. L., Milošević, D. M., \& Marisavljević, D. P. (2012). Characterization of sirodesmins isolated from the phytopathogenic fungus Leptosphaeria maculans. J. Serb. Chem. Soc. 77(10), 1363-1379.

Mitrović, P., \& Marinković, R. (2007). Phoma lingam - a rapeseed parasite in Serbia. Proc. of the 12th Intern. Rapeseed Congres Wuhan China. March 26-30 2007/ IV: 217-219.

Mitrović, P. (1997). Paraziti kupusa (Cabbage parasites). Master's Thesis. University of Novi Sad, Faculty of Agriculture.

Panjanin, M. (1965). Suva trulež kupusa (Phoma lingam). Biljna żaštita, 617, 133-135.

Pedras, M. S. C., \& Yu, Y. (2008). Stress-driven discovery of metabolites from the fungal plant pathogen Leptosphaeria maculans: 
structure and activity of leptomaculins. Bioorganic \& Medicinal Chemistry, 16, 8063-8071.

Pedras, M. S. C., Chumala, P. B., \& Yu, Y. (2007). The phytopathogenic fungi Leptosphaeria maculans and L. biglobosa: chemotaxonomical characterization of isolates and metabolite production in different culture media. Canadian Journal of Microbiology, 53, 364-371.

Pedras, M. S. C., \& Sguin-Swartz, G. (1992). The "Blackleg" Fungus: Phytotoxins and Phytoalexins. Canadian Journal of Phytopathology, 14, 67-75.

Petrie, G. A. (1988). The rapid differentiation of virulent and weakly virulent strains of Leptosphaeria maculans (blackleg or stem canker) and related pycnidial fungi from Brassica seeds and stems. Can. J. Plant Pathol. 10, 188-190.

Pound, S. G. (1947). Variability in Phoma lingam. Journal of Agricultural Research, 75(4), 113-133.

Punithalingam, E., \& Holliday, E. (1972). Leptospheria maculans CMI Descriptions of pathogenic fungi and Bacteria. No. 331.

Rouxel, T., \& Balesdent, M. H. ( 2005). The stem canker (blackleg) fungus, Leptosphaeria maculans, enters the genomic era. Molecular Plant Pathology, 6, 225-241.

Salisbury, P. A., Ballinger, D. J., Wratten, N., Plummer, K. M., \& Howlett, B. (1995). Blackleg disease on oilseed Brassica species in Australia: a review. Australian Journal of Experimental Agriculture, 35, 665-672.

Shoemaker, R. A., \& Brun, H. (2001). The teleomorph of the weakly aggressive segregate of Leptospheria maculans. Canadian Journal of Botany, 79, 412-419.
Somda, I., Harkous, S., \& Brun, H. (1997). Bipolar heterothelism in group isolates of Leptospheria maculans. Plant Pathology, 60, 890-896.

Szlàvik, S. Z., Jedryczka, M., Kiss, I., Lewartowska, E., \& Nagy, G. (2003). Population structure and pathogenicity grouping of $L$. maculans isolates from Hungary. Blackleg News, 3-4.

Thürwächter, F., Garbe, V., \& Hoppe, H. H. (1999). Ascospore discharge leaf infestation and variations in pathogenicity as criteria to predict impact of Leptosphaeria maculans on oilseed rape. Journal of Phytopathology, 147, 215-222.

Toscano-Underwood, C., West, J. S., Fitt, B. D. L., Todd, A. D., \& Jedryczka, M. (2001). Development of phoma lesions on oilseed rape leaves inoculated with ascospores of A-group or B-group Leptosphaeria maculans (stem canker) at different temperatures and wetness durations. Plant Pathology, 50, 28-41.

West, S. J., Biddulph, J. E., Fitt, B. D. L., \& Gladders, P. (1999). Epidemiology of Leptosphaeria maculans in relation to forecasting stem canker severity on winter oilseed rape in the UK. Ann. Appl. Biol. 135, 535-546.

West, S. J., Kharbanda, D. P., Barbeti, J. M., \& Fitt, L. D. B. (2001). Epidemiology and management of Leptosphaeria maculans (phoma stem canker) on oilseed rape in Australia Canada and Europe. Plant Pathology, 50, 10-27.

Williams, H. R., \& Fitt, L. D. B. (1999). Differentiating A and B groups of Leptospheria maculans causal agent of stem canker (blackleg) of oilseed rape. Plant Pathology, 48, 161-175.

Williams, P. H. (1992). Biology of Leptosphaeria maculans. Canadian Journal of Plant Pathology, 14, 30-35.

\section{Prva pojava raka stabla na uljanoj repici prouzrokovač Leptosphaeria biglobosa u Srbiji}

\section{Petar Mitrović · Ana Marjanović Jeromela · Vojislav Trkulja · Željko Milovac·Sreten Terzić}

Sažetak: U oktobru 2010. pojava simptoma raka stabla na uljanoj repici je uočena na lokalitetu Rimski šančevi u Srbiji. Nekoliko izolata gljive je izolovano iz stabla. Morfološke karakteristike 10 izolata izolovanih u Srbiji su proučene na PDA podlozi, na temperaturi $25 \pm 1{ }^{\circ} \mathrm{C}$ : rast, boja, oblik, izgled kolonija ivice kolonije, lučenje pigmenta, veličina, boja i oblik piknospora i piknida K-111, K-112, K-113, K-114, K-115, K-116, K-117, K-118, K119, K-120. Svi testirani izolati imaju brz porast, pravilan oblik kolonija i slabu sporulaciju na hranljivoj podlozi. Piknospore su jednoćelijske, hijalne, uglavnom prave, sa ili bez kapi ulja. Molekularna identifikacija je urađena upotrebom PCR tehnike korišćenjem prajmera PN3/PN10. Pored ovih izolata, dva referentna soja su dobijena iz Centra za poljoprivredna istraživanja Rothamsted, Ujedinjeno Kraljevstvo, i označeni sa L. m (Leptosphaeria maculans), L. b (Leptosphaeria biglobosa) i 7 izolata poreklom iz Srbije, označenih sa K-7, St-16, GS-25, L-5, C-3, LJ-2, S-1. Na osnovu DNK amplifikacije sa prajmerima PN3 i PN10 dužina je oko 580 bp (L.b, K-111, K-112, K-113, K-114, K115, K-116, K-117, K-118, K-119, K-120) dok kod drugih izolata (L.m, K-7, St-16, GS-25, L-5, C-3, LJ- 2, S-1) je $560 \mathrm{bp}$. Ova proučavanja su pokazala da svi ispitivani izolati (K-111, K-112, K-113, K-114, K-115, K-116, K-117, K118, K-119, K-120) izolovani iz prizemnog dela stabla uljane repice pripadaju vrsti Leptosphaeria biglobosa. Ključne reči: Leptosphaeria biglobosa, morfološke karakteristike, molekularne karakteristike, uljana repica 